\title{
Speciation of Rhenium in Chloride Melts: Spectroscopic and Electrochemical Study
}

\author{
Danil A. Danilova, Vladimir A. Volkovich ${ }^{\mathrm{a}}$, Boris D. Vasin ${ }^{\mathrm{a}}$, Denis E. Aleksandrov, \\ Ilya B. Polovov ${ }^{a}$, and Trevor R. Griffiths ${ }^{b}$ \\ ${ }^{a}$ Department of Rare Metals, Ural State Technical University, 620002 Ekaterinburg, Russia \\ $\mathrm{b}$ Redston Trevor Consulting Limited, Leeds, LS17 8RF, United Kingdom \\ Reprint requests to Dr. V. A. V.; E-mail: volkovich@dpt.ustu.ru \\ Z. Naturforsch. 63a, 371 - 376 (2008); received December 12, 2006
}

Presented at the EUCHEM Conference on Molten Salts and Ionic Liquids, Hammamet, Tunisia, September 16-22, 2006.

\begin{abstract}
Speciation of rhenium in high-temperature alkali chloride-based melts was studied using electronic absorption and IR spectroscopy of molten salts and diffuse reflectance spectroscopy of quenched melts. Rhenium was added to the melts by anodic dissolution of the metal (at anodic current densities of $0.005-0.05 \mathrm{~A} / \mathrm{cm}^{2}$ ), by reacting $\mathrm{Re}$ and $\mathrm{ReO}_{2}$ with $\mathrm{Cl}_{2}$ and $\mathrm{HCl}$, and by dissolving $\mathrm{K}_{2}\left[\mathrm{ReCl}_{6}\right]$. The melts included $3 \mathrm{LiCl}-2 \mathrm{KCl}$ and $\mathrm{NaCl}-2 \mathrm{CsCl}$ eutectics, an $\mathrm{NaCl}-\mathrm{KCl}$ equimolar mixture, and pure $\mathrm{NaCl}, \mathrm{KCl}$ and $\mathrm{CsCl}$ between 450 and $850{ }^{\circ} \mathrm{C}$. Rhenium was present in the melts as $\mathrm{Re}(\mathrm{IV})$ hexachloro-ions, $\left[\mathrm{ReCl}_{6}\right]^{2-}$; no evidence of species containing rhenium in oxidation states below four was obtained. The kinetics of $\left[\mathrm{ReCl}_{6}\right]^{2-}$ disproportionation in molten alkali chlorides were investigated, and the IR spectra of $\left[\mathrm{ReO}_{4}\right]^{-}$ions in molten CsCl-CsI and CsI were measured for the first time.
\end{abstract}

Key words: Rhenium; Rhenium Chlorides; Chloride Melts; Electronic Absorption Spectroscopy.

\section{Introduction}

Electrolytic reduction of rhenium from chloride melts is a prospective method for obtaining high-purity metal. Knowing the speciation of rhenium and the stability of its ions in such media is important for optimizing the methods of preparing rhenium-containing melts and processes of rhenium electrowinning. Only a few works were devoted to investigating the behaviour of rhenium in alkali halide melts and other ionic media.

Electronic absorption spectra of solutions of $\mathrm{K}_{2}\left[\mathrm{ReCl}_{6}\right]$ have been measured in molten $3 \mathrm{LiCl}-$ $2 \mathrm{KCl}$ eutectic and dimethyl sulfone between 135 and $600{ }^{\circ} \mathrm{C}$ [1]. The behaviour of $\operatorname{Re}(\mathrm{III})$ chloride species, $\mathrm{Re}_{3} \mathrm{Cl}_{9},\left[\mathrm{Re}_{3} \mathrm{Cl}_{12}\right]^{3-}$ and $\left[\mathrm{Re}_{2} \mathrm{Cl}_{8}\right]^{2-}$, in the same melts has also been investigated [2]. In a 3LiCl-2KCl melt $\mathrm{Re}(\mathrm{III})$ disproportionates to $\operatorname{Re}(0)$ and $\left[\mathrm{ReCl}_{6}\right]^{2-}$. Raman spectroscopy was employed to study the reaction of rhenium metal with molten lithium perchlorate at $250-300{ }^{\circ} \mathrm{C}$ [3]; perrhenate was the only product formed. Bailey and Nobile [4] conducted an electrochemical study of rhenium in molten $3 \mathrm{LiCl}-2 \mathrm{KCl}$ eutectic at $450-550{ }^{\circ} \mathrm{C}$. They found that anodic dissolution of rhenium results in a mixture of $\operatorname{Re}(\mathrm{III})$ and $\operatorname{Re}(\mathrm{IV})$ chloride complexes; $\operatorname{Re}(\mathrm{III})$ ions disproportionate to $\operatorname{Re}(0)$ and $\operatorname{Re}(\mathrm{IV})$. Upon dissolving $\mathrm{K}_{2}\left[\mathrm{ReCl}_{6}\right]$ in the same melt, the authors [4] noted partial decomposition of this salt to Re metal and volatile $\mathrm{ReCl}_{5}$. However, in their opinion, after complete dissolution the decomposition reaction ceased and rhenium(IV) complexes, $\left[\mathrm{ReCl}_{6}\right]^{2-}$, stabilized. Stepanov et al. [5] conducted electrochemical studies of $\mathrm{Re}$ in an $\mathrm{NaCl}-\mathrm{KCl}$ melt and concluded that $\operatorname{Re}(\mathrm{IV})$ and $\operatorname{Re}(\mathrm{V})$ ions are present in the melt in equilibrium with rhenium metal. Later Stepanov et al. [6] studied the anodic dissolution of rhenium and found that at a current density of $0.4-$ $1.2 \mathrm{~A} / \mathrm{cm}^{2} \mathrm{Re}$ dissolves, giving out four electrons; at current densities below $0.15 \mathrm{~A} / \mathrm{cm}^{2}$ the number of electrons falls below four. Electronic absorption spectra of $\mathrm{Re}(\mathrm{III})$ and $\mathrm{Re}(\mathrm{IV})$ ions $\left(\left[\mathrm{Re}_{2} \mathrm{Cl}_{8}\right]^{2-},\left[\mathrm{Re}_{2} \mathrm{Cl}_{8}\right]^{3-}\right.$, $\left.\mathrm{Re}_{3} \mathrm{Cl}_{9},\left[\mathrm{ReCl}_{6}\right]^{2-},\left[\mathrm{Re}_{2} \mathrm{Cl}_{9}\right]^{-},\left[\mathrm{Re}_{2} \mathrm{Cl}_{9}\right]^{2-}\right)$ were also measured in low-temperature ionic melts based on 1-methyl-3-ethylimidazolium chloroaluminate and $\mathrm{AlCl}_{3}-\mathrm{NaCl}[7-9]$. On the basis of electrochemical studies of the rhenium behaviour in fused alkali chlo- 
rides Kuznetsov [10] concluded that only Re(III) ions are present in molten $\mathrm{NaCl}$, and only $\mathrm{Re}(\mathrm{IV})$ in molten $\mathrm{KCl}$ and $\mathrm{CsCl}$. This was explained by the effect of the outer sphere cations onto rhenium chloro-complexes due to differences in the ionic potentials of alkali metal cations. Kuznetsov [10] also suggested that disproportionation of $\operatorname{Re}(\mathrm{III})$ and $\operatorname{Re}(\mathrm{IV})$ ions observed in earlier works results from the interaction of rhenium chlorides with silica, leading to the formation of higher oxidation state rhenium oxychlorides and Re metal. Volkovich et al. [11] employed high-temperature spectroscopy to study reactions of $\mathrm{Re}, \mathrm{ReO}_{2}$ and $\mathrm{ReO}_{3}$ with $\mathrm{Cl}_{2}$ and $\mathrm{HCl}$ in various alkali metal chlorides between 450 and $720{ }^{\circ} \mathrm{C}$. They found that $\operatorname{Re}(0)$ reacts with $\mathrm{Cl}_{2}$ in an $\mathrm{NaCl}-2 \mathrm{CsCl}$ eutectic forming only $\operatorname{Re}(\mathrm{IV})$ complex ions. Spectra measured during chlorination of $\mathrm{Re}$ in $3 \mathrm{LiCl}-2 \mathrm{KCl}$ and $\mathrm{NaCl}-\mathrm{KCl}$ melts in addition to $\left[\mathrm{ReCl}_{6}\right]^{2-}$ bands contained some additional absorption bands. Reaction of rhenium oxides with $\mathrm{Cl}_{2}$ or $\mathrm{HCl}$ in an $\mathrm{NaCl}-2 \mathrm{CsCl}$ melt results in the formation of $\operatorname{Re}(\mathrm{IV})$ ions.

In the present work electronic absorption and IR spectroscopy of molten salts and diffuse reflectance spectroscopy of quenched melts was used to study the speciation of rhenium in molten alkali metal chlorides and their mixtures. Rhenium was added to the melts by anodic dissolution of the metal, by reacting $R e$ and $\mathrm{ReO}_{2}$ with $\mathrm{Cl}_{2}$ and $\mathrm{HCl}$, and by dissolving $\mathrm{K}_{2}\left[\mathrm{ReCl}_{6}\right]$ and $\mathrm{Na}\left[\mathrm{ReO}_{4}\right]$. The studied melts included $3 \mathrm{LiCl}-2 \mathrm{KCl}$ and $\mathrm{NaCl}-2 \mathrm{CsCl}$ eutectics, an $\mathrm{NaCl}-\mathrm{KCl}$ equimolar mixture, and pure $\mathrm{NaCl}, \mathrm{KCl}$ and $\mathrm{CsCl}$ between 450 and $850{ }^{\circ} \mathrm{C}$. The kinetics of $\left[\mathrm{ReCl}_{6}\right]^{2-}$ decomposition were investigated, and for the first time the IR spectra of $\left[\mathrm{ReO}_{4}\right]^{-}$ions were measured in molten CsI and CsI-CsCl.

\section{Experimental}

Electronic absorption spectra were recorded using a system based on a fibre optics Ocean Optics SD2000 spectrometer and an optical hightemperature furnace [11]. Melts were contained in standard high-temperature $1 \mathrm{~cm}$ path length silica optical cells. Spectral data were collected in the 250 $1100 \mathrm{~nm}$ range. IR emission spectra were registered using a SPECORD M80 spectrophotometer with a special high-temperature optical attachment with a CsI window [12]. A previously described system [13] was used for in situ spectroscopy studies of anodic dissolution. Diffuse reflectance spectra of powdered quenched melts were measured using a setup described earlier [14]. When required, the experimental spectra were resolved into individual overlapping bands using PeakFit version 4.01 software.

The experiments were performed in molten individual $\mathrm{NaCl}, \mathrm{KCl}$ and $\mathrm{CsCl}, 3 \mathrm{LiCl}-2 \mathrm{KCl}$ and $\mathrm{NaCl}-2 \mathrm{CsCl}$ eutectics and an $\mathrm{NaCl}-\mathrm{KCl}$ equimolar mixture. Individual reagent grade alkali metal chlorides were dried for $3 \mathrm{~h}$ at $300{ }^{\circ} \mathrm{C}$ and then melted. Molten salts were sparged with chlorine and hydrogen chloride for $5 \mathrm{~h}$ and then held under vacuum. Mixtures of required compositions were prepared by fusing individual chlorides in vacuo and then subjected to zone recrystallization under vacuum.

Rhenium was added to the melts by anodic dissolution of metal (99.99\% purity) at anodic current densities of $0.005-0.05 \mathrm{~A} / \mathrm{cm}^{2}$, by chlorinating Re and $\mathrm{ReO}_{2}$ by $\mathrm{Cl}_{2}$ and $\mathrm{HCl}$ bubbled through the melts at a rate of $10-60 \mathrm{~cm}^{3} \mathrm{~min}^{-1}$, and by directly dissolving $\mathrm{K}_{2}\left[\mathrm{ReCl}_{6}\right]$ and $\mathrm{Na}\left[\mathrm{ReO}_{4}\right]$. All the processes (chlorination and dissolution) were followed by in situ spectroscopy measurements. $\mathrm{K}_{2}\left[\mathrm{ReCl}_{6}\right]$ was prepared from $\mathrm{K}\left[\mathrm{ReO}_{4}\right]$ following a standard procedure [15]. Chlorine was generated by electrolysis of molten lead chloride, and $\mathrm{HCl}$ by reaction of conc. $\mathrm{H}_{2} \mathrm{SO}_{4}$ with $\mathrm{NaCl}$. For anodic dissolution a piece of rhenium (owing to a very positive electrode potential) was suspended on a carbon thread, which also acted as a current conductor. A molybdenum wire dipped in a melt containing $\mathrm{PbCl}_{2}$, held in a silica tube separated from the bulk of the melt by a diaphragm, acted as the cathode. For spectroelectrochemical measurements the optical cell also contained a glassy carbon working electrode $\left(S=0.032 \mathrm{~cm}^{2}\right)$ and an $\mathrm{Ag} / \mathrm{AgCl}(1 \mathrm{~mol} \%$ in NaCl$2 \mathrm{CsCl})$ reference electrode. A PI-50-1.1 potentiostat was used for all the electrochemical measurements.

After every experiment samples of the melts (1$2 \mathrm{~cm}^{3}$ ) were sucked into silica capillary tubes, using a syringe, and quickly quenched. The concentration of rhenium in these samples was determined photometrically with thiourea [16].

\section{Results and Discussion}

$\mathrm{Re}$ anodic dissolution was studied in $3 \mathrm{LiCl}-2 \mathrm{KCl}$, $\mathrm{NaCl}$ and $\mathrm{NaCl}-2 \mathrm{CsCl}$ melts at $450-850{ }^{\circ} \mathrm{C}$ at anodic current densities between 0.005 and $0.05 \mathrm{~A} / \mathrm{cm}^{2}$. The profiles of the spectral curves in all these melts at all studied temperatures and current densities were qualitatively similar (an example is given in Fig. 1) 


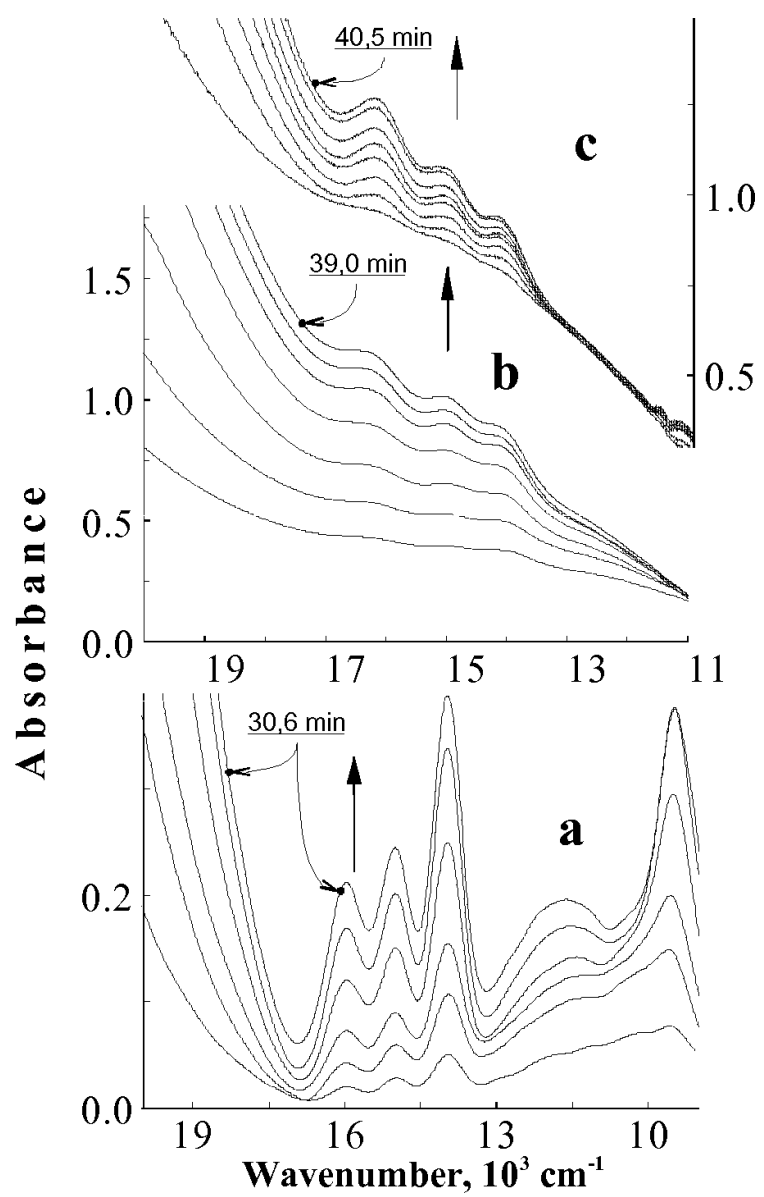

Fig. 1. Electronic absorption spectra recorded during anodic dissolution of $\mathrm{Re}$ in molten (a) $\mathrm{NaCl}-2 \mathrm{CsCl}$ at $550^{\circ} \mathrm{C}$, (b) $\mathrm{NaCl}$ and (c) $\mathrm{NaCl}-2 \mathrm{CsCl}$ at $850{ }^{\circ} \mathrm{C}$. Final Re concentration in melts was 14,18 and $1 \mathrm{mmol} / \mathrm{l}$, respectively.

and characteristic of the absorption of rhenium(IV) $\left[\mathrm{ReCl}_{6}\right]^{2-}$ ions. Observed absorption bands arise from the following spin-forbidden electronic transitions in $\left[\mathrm{ReCl}_{6}\right]^{2-}$ complex ions: ${ }^{4} \mathrm{~A}_{2 \mathrm{~g}}\left(\Gamma_{8}\right) \rightarrow{ }^{2} \mathrm{~T}_{2 \mathrm{~g}}\left(\Gamma_{8}\right)$ at 15000 and $16000 \mathrm{~cm}^{-1} ;{ }^{4} \mathrm{~A}_{2 \mathrm{~g}}\left(\Gamma_{8}\right) \rightarrow{ }^{2} \mathrm{~T}_{2 \mathrm{~g}}\left(\Gamma_{7}\right)$ at $14000 \mathrm{~cm}^{-1}$; and ${ }^{4} \mathrm{~A}_{2 \mathrm{~g}}\left(\Gamma_{8}\right) \rightarrow{ }^{2} \mathrm{E}_{\mathrm{g}}\left(\Gamma_{8}\right)$ and ${ }^{4} \mathrm{~A}_{2 \mathrm{~g}}\left(\Gamma_{8}\right) \rightarrow$ ${ }^{2} \mathrm{~T}_{1 \mathrm{~g}}\left(\Gamma_{6}\right)$ at $9100-9500 \mathrm{~cm}^{-1}$. Bands at 15000 and $16000 \mathrm{~cm}^{-1}$ result from the term splitting due to spin-orbit coupling. The nature of the broad band at $11600 \mathrm{~cm}^{-1}$ is not yet clear. More intense bands, originating from the spin-allowed transitions, are situated at higher energies and could not be registered using the present experimental setup. The obtained energy values correspond to literature data $[1,2,10]$. No bands indicating the possible existence of $\operatorname{Re}(\mathrm{III})$ ions in $\mathrm{NaCl}$ or $3 \mathrm{LiCl}-2 \mathrm{KCl}$ melts were observed. IR spectra

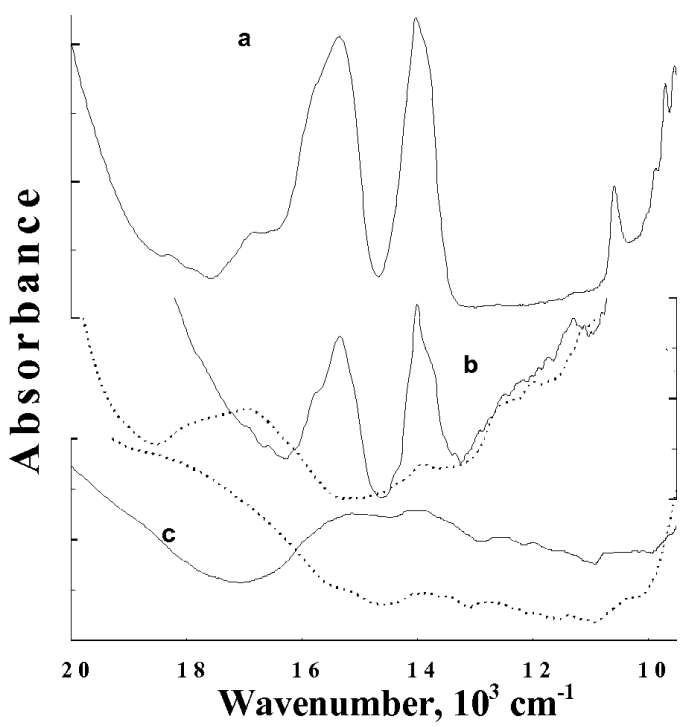

Fig. 2. Diffuse reflectance spectra of (a) pure $\mathrm{K}_{2}\left[\mathrm{ReCl}_{6}\right]$, and green (dashed line) and yellow (solid line) parts of quenched melt samples after anodic dissolution of rhenium in (b) NaCl$2 \mathrm{CsCl}$ and (c) $\mathrm{NaCl}$ melts.

of quenched melt samples contained the peaks corresponding to the " $\mathrm{Re}^{\mathrm{IV}} \mathrm{Cl}_{6}$ " moiety of $O_{h}$ symmetry. There were no bands that could be attributed to perrhenate, oxychloro- or polynuclear rhenium species.

It was noticed that the colour of quenched melt samples depended on the rate of quenching. Slowly quenched samples were yellow, and their diffuse reflectance spectra included bands at 14000 and $15400 \mathrm{~cm}^{-1}$ corresponding to $\mathrm{M}_{2}\left[\mathrm{ReCl}_{6}\right]$ (Fig. 2). Rapidly quenched samples were brownish-green, and their diffuse reflectance spectra contained an additional band around $16700-18200 \mathrm{~cm}^{-1}$, seen as a shoulder in the experimental spectrum. This band probably corresponds to one of the products of disproportionation of $\left[\mathrm{ReCl}_{6}\right]^{2-}$, occurring at sudden melt quenching.

A special series of experiments was performed to study the stability of the $\left[\mathrm{ReCl}_{6}\right]^{2-}$ complex in chloride melts. Samples of pure $\mathrm{K}_{2} \mathrm{ReCl}_{6}$ were dissolved in selected melts under argon, and the absorption spectra were recorded over time. The Re(IV) concentration in the melts gradually decreased, Fig. 3, and did stabilize as reported by Bailey and Nobile [4]. At the same time a dark-blue compound, presumably $\mathrm{ReCl}_{5}$, was subliming from the melt and condensing in the upper cold part of the cell. Chemical analysis of this compound showed the presence of rhenium, however, the small amount of this sublimate and its hygroscopic nature did not allow to perform more detailed charac- 


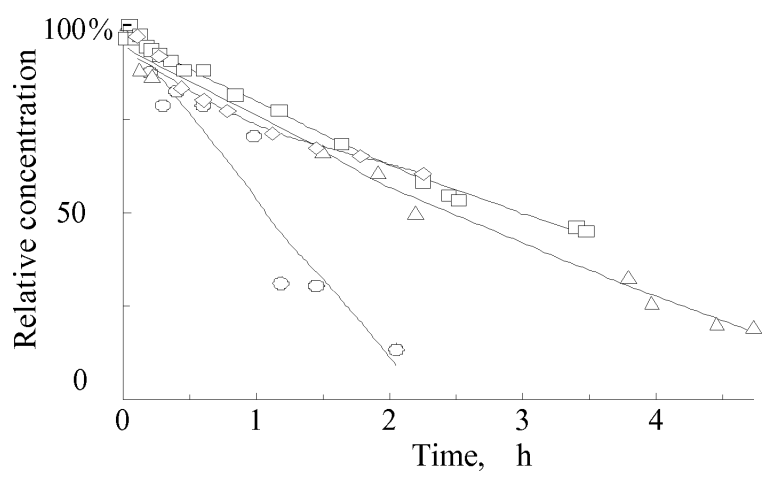

Fig. 3. Decreasing $\left[\mathrm{ReCl}_{6}\right]^{2-}$ concentration (relative) over time at $750{ }^{\circ} \mathrm{C}$ in molten alkali chlorides: $\square, \mathrm{NaCl}-\mathrm{KCl}$; $\circ, 3 \mathrm{LiCl}-2 \mathrm{KCl} ; \triangle, \mathrm{NaCl}-2 \mathrm{CsCl} ; \diamond, \mathrm{CsCl}$.

terization. If the cell was evacuated, the concentration of $\left[\mathrm{ReCl}_{6}\right]^{2-}$ in the melt rapidly decreased. This fact also supports the assumption that one of the products of $\left[\mathrm{ReCl}_{6}\right]^{2-}$ decomposition must be volatile. The decomposition most likely proceeds according to the following scheme, proposed by Bailey and Nobile [4]:

$$
\begin{aligned}
& 2 \mathrm{M}_{2}\left[\mathrm{ReCl}_{6}\right]=\mathrm{ReCl}_{5} \uparrow+\mathrm{ReCl}_{3}+4 \mathrm{MCl}, \\
& 4 \mathrm{ReCl}_{3}+6 \mathrm{MCl}=\mathrm{Re}+3 \mathrm{M}_{2}\left[\mathrm{ReCl}_{6}\right] .
\end{aligned}
$$

With the exception of lithium-containing chloride melts, the cationinc composition of the melt did not significantly affect the rate of $\left[\mathrm{ReCl}_{6}\right]^{2-}$ decomposition (Fig. 3). Increasing temperature resulted in increased rates of decomposition in all studied systems. It is quite likely that formed rhenium pentachloride, $\mathrm{ReCl}_{5}$, partially dissolves in the melt, and $\mathrm{Re}(\mathrm{V})$ chloride ions, $\left[\mathrm{ReCl}_{6}\right]^{-}$, absorb in the $\mathrm{UV}$ region of the spectrum. However, since $\left[\mathrm{ReCl}_{6}\right]^{2-}$ ions strongly absorb above $19000 \mathrm{~cm}^{-1}$ the effect of $\operatorname{Re}(\mathrm{V})$ onto the profile of the spectral curve cannot be observed under the studied conditions.

A series of spectroelectrochemical experiments in $3 \mathrm{LiCl}-2 \mathrm{KCl}$ and $\mathrm{NaCl}-\mathrm{KCl}$ melts was performed at 550 and $750{ }^{\circ} \mathrm{C}$, respectively, to check Kuznetsov's [10] suggestion about the possibility of stabilizing Re(III) ions in alkali chloride melts with small cations. Rhenium metal was anodically dissolved in these melts, forming $\left[\mathrm{ReCl}_{6}\right]^{2-}$, and cyclic voltammograms were then measured to determine suitable reduction potentials. An example of a cyclic voltammogram is shown in Fig. 4; it exhibits two anodic and two cathodic waves and agrees with the data reported by Kuznetsov [10] for $2 \mathrm{NaCl}-3 \mathrm{KCl}, \mathrm{KCl}$ and $\mathrm{CsCl}$ melts. According to Kuznetsov [10] only one cathodic and

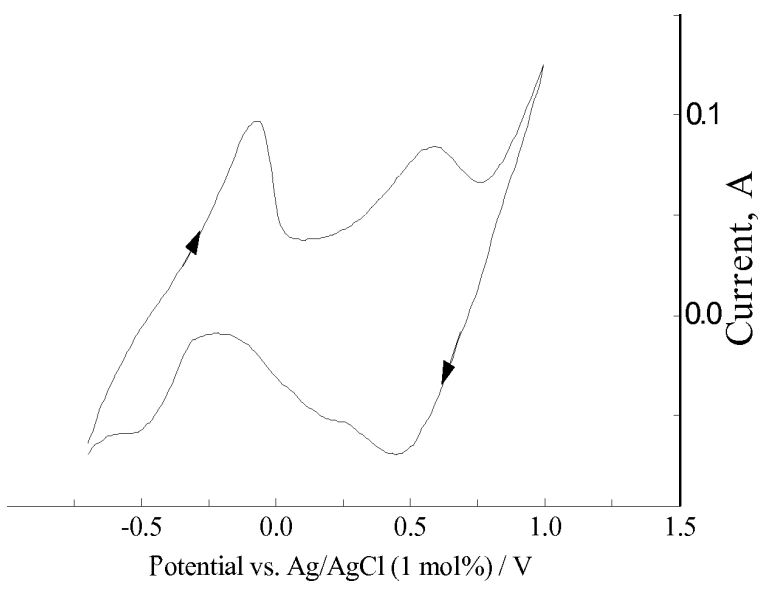

Fig. 4. Cyclic voltammogram of $\left[\mathrm{ReCl}_{6}\right]^{2-}$ containing $\mathrm{NaCl}$ $\mathrm{KCl}$-based melt at $750{ }^{\circ} \mathrm{C}$ prepared by anodic dissolution of Re metal. Working electrode, glassy carbon $\left(S=0.032 \mathrm{~cm}^{2}\right)$; reference electrode, $\mathrm{Ag} / \mathrm{AgCl}(1 \mathrm{~mol} \%$ in $\mathrm{NaCl}-2 \mathrm{CsCl})$; counter electrode, molybdenum wire in $\mathrm{NaCl}-2 \mathrm{CsCl}+\mathrm{PbCl}_{2}$; rest potential, $+0.82 \mathrm{~V}$; scan rate, $0.1 \mathrm{~V} / \mathrm{s}$; initial Re content, $0.8 \mathrm{wt} \%$.

one anodic peak (corresponding to the $\operatorname{Re}(\mathrm{III}) / \operatorname{Re}(0)$ redox couple) should be expected in $3 \mathrm{LiCl}-2 \mathrm{KCl}$ and $\mathrm{NaCl}-\mathrm{KCl}$ melts; but in both these melts we observed two reduction and two oxidation waves.

Assuming that the reduction peaks in the cyclic voltammograms, Fig. 4, correspond to $\operatorname{Re}(\mathrm{IV}) \rightarrow$ $\operatorname{Re}(\mathrm{III})$ and $\operatorname{Re}(\mathrm{III}) \rightarrow \operatorname{Re}(0)$ reactions, the potentiostatic reduction of rhenium-containing melts was conducted at potentials ranging from +0.2 to $-0.1 \mathrm{~V}$. During the reduction the concentration of $\operatorname{Re}(\mathrm{IV})$ in the melt gradually decreased, but no new peaks in the spectra, that could be attributed to lower oxidation state rhenium ions, appeared. At the end of the reduction (taking $1.5-3.5 \mathrm{~h}$ ) the melt contained a fine precipitate of metallic rhenium, and the content of rhenium in the melt was low $(0.007-0.065 \mathrm{wt} \%$ in various experiments). It seems that $\operatorname{Re}(\mathrm{III})$ ions can only be formed near the electrode surface during the cathodic reduction of $\operatorname{Re}(\mathrm{IV})$ ions, and can be detected by electrochemical methods, but cannot be stabilized in the bulk of the melt in spectroscopically detectable amounts, at least when using silica optical cells.

The reaction of metallic rhenium with chlorine in chloride melts resulted in the formation of $\left[\mathrm{ReCl}_{6}\right]^{2-}$ ions (Fig. 5). Studying this reaction in various molten alkali chlorides showed that the cationic composition of the melt affects the rate of the chlorination (Table 1). Compact rhenium (used as a piece with a total surface area around $0.6 \mathrm{~cm}^{2}$ ) or Re metal powder 
Table 1. Chlorination of $\mathrm{Re}$ and $\mathrm{ReO}_{2}$ in alkali chloride melts.

\begin{tabular}{lccccc}
\hline Melt & Compound & $T,{ }^{\circ} \mathrm{C}$ & Chlorinating agent & Time of chlorination, h & Max. conc. of Re in melt, mmol/l \\
\hline $\mathrm{NaCl}-2 \mathrm{CsCl}$ & $\mathrm{Re}$ (powder) & 750 & $\mathrm{Cl}_{2}$ & 4.8 & 0.9 \\
$\mathrm{NaCl}-\mathrm{KCl}$ & $\mathrm{Re}$ (powder) & 800 & $\mathrm{Cl}_{2}$ & 1.1 & 38.4 \\
$\mathrm{CsCl}$ & $\mathrm{Re}$ (powder) & 800 & $\mathrm{Cl}_{2}$ & 3.0 & 10.4 \\
$\mathrm{NaCl}-\mathrm{KCl}$ & $\mathrm{Re}$ (piece) & 850 & $\mathrm{Cl}_{2}$ & 1.2 & not found \\
$\mathrm{NaCl}-2 \mathrm{CsCl}$ & $\mathrm{Re}$ (piece) & 850 & $\mathrm{Cl}_{2}$ & 1.7 & 7.8 \\
$\mathrm{NaCl}-2 \mathrm{CsCl}$ & $\mathrm{ReO}_{2}$ & 650 & $\mathrm{Cl}_{2}$ & 0.9 & 20.7 \\
$\mathrm{NaCl}-\mathrm{KCl}$ & $\mathrm{ReO}_{2}$ & 750 & $\mathrm{Cl}_{2}$ & 6.7 & 3.4 \\
$3 \mathrm{LiCl}-2 \mathrm{KCl}$ & $\mathrm{ReO}_{2}$ & 500 & $\mathrm{HCl}$ & 3.5 & not found \\
$\mathrm{NaCl}-\mathrm{KCl}$ & $\mathrm{ReO}_{2}$ & 750 & $\mathrm{HCl}$ & 4.1 & not found \\
$\mathrm{NaCl}-2 \mathrm{CsCl}$ & $\mathrm{ReO}_{2}$ & 600 & $\mathrm{HCl}$ & 3.5 & 24.8 \\
$\mathrm{NaCl}-2 \mathrm{CsCl}$ & $\mathrm{ReO}_{2}$ & 800 & $\mathrm{HCl}$ & 4.7 & not found \\
$\mathrm{KCl}$ & $\mathrm{ReO}_{2}$ & 850 & $\mathrm{HCl}$ & & not found \\
\hline
\end{tabular}

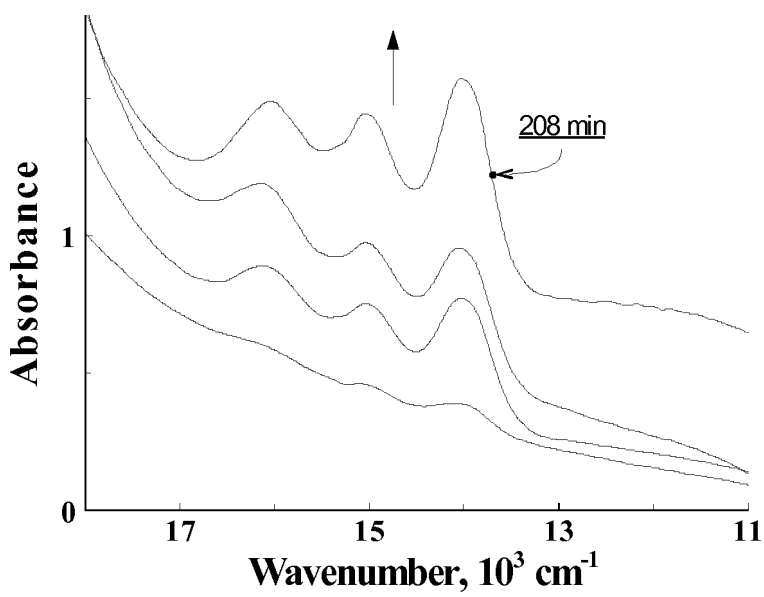

Fig. 5. Electronic absorption spectra recorded during reaction of metallic rhenium with chlorine in an $\mathrm{NaCl}-2 \mathrm{CsCl}$ melt at $750{ }^{\circ} \mathrm{C}$. Final Re concentration in the melt was $0.04 \mathrm{~mol} / \mathrm{l}$.

(20 $\mathrm{mg}$ per $1 \mathrm{~cm}^{3}$ of the melt) were used for this study. Data in the table show that the rate of chlorination increases with increasing radius of alkali metal cations, due to the increasing solubility of chlorine.

The reaction of rhenium dioxide with $\mathrm{Cl}_{2}$ or $\mathrm{HCl}$ in alkali chloride melts (approx. $15 \mathrm{mg} \mathrm{ReO}_{2}$ per $1 \mathrm{~cm}^{3}$ of the melt) also results mainly in the formation of $\left[\mathrm{ReCl}_{6}\right]^{2-}$ complex ions in the melt. When $\mathrm{ReO}_{2}$ reacted with chlorine, the rate of accumulation of $\left[\mathrm{ReCl}_{6}\right]^{2-}$ in the melt was $6 \cdot 10^{-8} \mathrm{~mol} / \mathrm{min}$ in $\mathrm{NaCl}-$ $\mathrm{KCl}$ at $750{ }^{\circ} \mathrm{C}$ and $2.1 \cdot 10^{-7} \mathrm{~mol} / \mathrm{min}$ in $\mathrm{NaCl}-$ $2 \mathrm{CsCl}$ at $650{ }^{\circ} \mathrm{C}$. The rate of the reaction of $\mathrm{ReO}_{2}$ with $\mathrm{HCl}$ was somewhat lower. After several hours of reaction the concentration of $\left[\mathrm{ReCl}_{6}\right]^{2-}$ in $3 \mathrm{LiCl}$ $2 \mathrm{KCl}$ at $500{ }^{\circ} \mathrm{C}, \mathrm{NaCl}-\mathrm{KCl}$ at $750{ }^{\circ} \mathrm{C}, \mathrm{NaCl}-2 \mathrm{CsCl}$ at $800{ }^{\circ} \mathrm{C}$ and $\mathrm{KCl}$ at $850{ }^{\circ} \mathrm{C}$ did not reach spectroscopically detectable levels. In the $\mathrm{NaCl}-2 \mathrm{CsCl}$ eutectic at $600{ }^{\circ} \mathrm{C}$ the rate of accumulation of $\left[\mathrm{ReCl}_{6}\right]^{2-}$ was $10^{-7} \mathrm{~mol} / \mathrm{min}$.

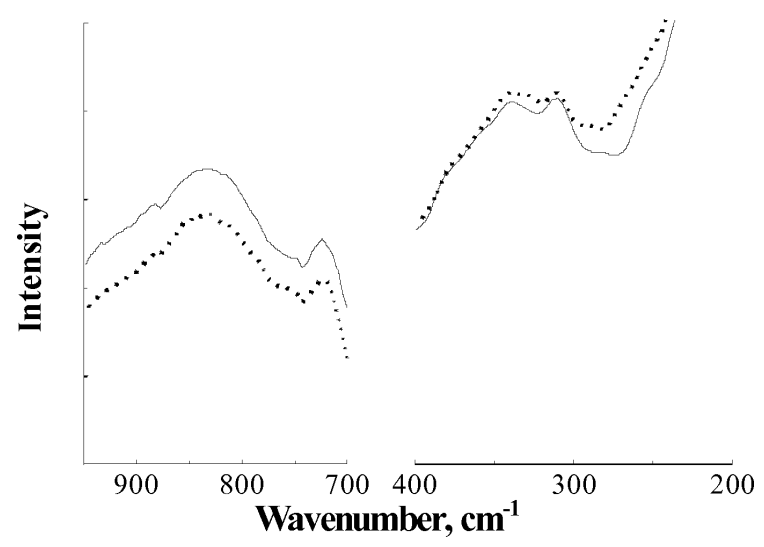

Fig. 6. IR emission spectra of $\left[\mathrm{ReO}_{4}\right]^{-}$solution in molten CsI (solid line) and $85 \% \mathrm{CsI}-15 \% \mathrm{CsCl}$ (dotted line) at $600{ }^{\circ} \mathrm{C}$.

Another rhenium species stable in high-temperature melts is perrhenate, $\left[\mathrm{ReO}_{4}\right]^{-}$. This species, however, does not absorb in the visible region (only a lowenergy edge of the charge transfer spectrum lying above $31200 \mathrm{~cm}^{-1}$ was observed in $\mathrm{NaCl}-2 \mathrm{CsCl}$ melt), and for its detection IR spectroscopy of molten salts had to be employed. Since alkali chloride melts absorb strongly below $500-300 \mathrm{~cm}^{-1}$ we used another solvent, CsI, transparent in that region. The IR spectra of $\mathrm{Na}\left[\mathrm{ReO}_{4}\right]$ dissolved in molten CsI and CsI-CsCl $(15 \%)$ at $600{ }^{\circ} \mathrm{C}$ are shown in Figure 6. Two bands in the spectra were attributed to vibrations in the $\left[\mathrm{ReO}_{4}\right]^{-}$ ion of $T_{d}$ symmetry, degenerated stretching vibration $v_{\mathrm{d}}(\mathrm{Re}-\mathrm{O})$ at $835 \mathrm{~cm}^{-1}$ and degenerated bending vibration $\delta_{\mathrm{d}}(\mathrm{O}-\mathrm{Re}-\mathrm{O})$ at $330-315 \mathrm{~cm}^{-1}$. The nature of the band around $725 \mathrm{~cm}^{-1}$ is not clear.

\section{Conclusions}

The conducted spectroscopy studies showed that $\left[\mathrm{ReCl}_{6}\right]^{2-}$ and $\left[\mathrm{ReO}_{4}\right]^{-}$ions are stable in high- tem- 
perature chloride melts. Anodic dissolution of Re independently of the cationic composition of the melt and anodic current densities (in the range of $0.005-$ $0.05 \mathrm{~A} / \mathrm{cm}^{2}$ ) resulted in the formation of $\mathrm{Re}(\mathrm{IV})$ ions, $\left[\mathrm{ReCl}_{6}\right]^{2-}$. No absorption bands that could be attributed to $\operatorname{Re}(\mathrm{III})$ ions were observed in the spectra

[1] R. A. Bailey and J. A. McIntyre, Inorg. Chem. 5, 964 (1966).

[2] R. A. Bailey and J. A. McIntyre, Inorg. Chem. 5, 1940 (1966).

[3] D. Cohen, S. Fried, and H. Selig, J. Inorg. Nucl. Chem. 33, 2687 (1971).

[4] R. A. Bailey and A. A. Nobile, Electrochim. Acta 17, 1139 (1972).

[5] A.D. Stepanov, S. N. Shkolnikov, A. M. Ezrokhina, and U. V. Boboshkin, Izv. Vuzov, Tsvet. Met. 5, 65 (1985).

[6] A. D. Stepanov, M. M. Vetyukov, and S. N. Shkolnikov, in: V. Urals Conference on High Temperature Physics, Chemistry and Electrochemistry, Vol. 1, Sverdlovsk, 1989, p. 230.

[7] S. K. D. Strubinger, I.-W. Sun, W. E. Cleland, Jr., and C. L. Hussey, Inorg. Chem. 29, 993 (1990).

[8] S. K. D. Strubinger, I.-W. Sun, W. E. Cleland, Jr., and C. L. Hussey, Inorg. Chem. 29, 4246 (1990). measured during anodic dissolution. Chlorination of metallic $\mathrm{Re}$ or $\mathrm{ReO}_{2}$ by $\mathrm{Cl}_{2}$ or $\mathrm{HCl}$ and dissolution of $\mathrm{K}_{2}\left[\mathrm{ReCl}_{6}\right]$ in the melts of various cationic compositions and in a wide temperature range led to the formation of $\mathrm{Re}(\mathrm{IV})$ ions in the melt. $\left[\mathrm{ReCl}_{6}\right]^{2-}$ slowly disproportionated forming $\mathrm{Re}$ metal and volatile $\mathrm{ReCl}_{5}$.

[9] S. K. D. Strubinger, W. E. Cleland, and C. L. Hussey, Inorg. Chem. 30, 4276 (1991).

[10] S. A. Kuznetsov, Elektrokhimiya 30, 1462 (1994).

[11] V. A. Volkovich, I. May, J. M. Charnock, and B. Lewin, Phys. Chem. Chem. Phys. 4, 5753 (2002).

[12] A. A. Khokhryakov, Electronic and Infrared Spectra of Oxyhalide Melts: Dilute Solutions, DSc Thesis, Institute of Metallurgy, Ekaterinburg, Russia 1999 (in Russian).

[13] I. B. Polovov, V. A. Volkovich, S. A. Shipulin, S. V. Maslov, A. A. Khokhryakov, B. D. Vasin, T. R. Griffiths, and R. C. Thied, J. Mol. Liquids 105, 105 (2003).

[14] T. R. Griffiths, V.A. Volkovich, D. J. Fray, and M. Fields, Dyes and Pigments 39, 139 (1998).

[15] C.L. Rulfs and R. S. Meyer, J. Am. Chem. Soc. 77, 4505 (1955).

[16] A. I. Lazarev, Organic Reagents in Analysis of Metals, Metallurgiya, Moscow 1980, p. 232 (in Russian). 